\title{
Analysis Of The Effect Of Islamic Product Attributes, Servicescape, And Interpersonal Communications On Customer Satisfaction Bank BTN Syariah KCPS Ngaliyan
}

\author{
Nurudin', Khoirul Anwar ${ }^{2}$, Hidayaturrosyida ${ }^{3}$ \\ 1,2,3 Walisongo State Islamic University, Semarang, Indonesia. \\ nurudin@walisongo.ac.id
}

\begin{abstract}
Purpose - This study aims to determine the effect of Islamic product attributes, service scape, interpersonal communication on customer satisfaction at Bank BTN Syariah KCPS Ngaliyan.

Method - The method used in this research is quantitative method, where this method is carried out by distributing questionnaires to BTN Syariah KCPSNgaliyan customers. Samples were taken as many as 100 respondents with incidental sampling technique.

Result - The results show that the variable attributes of Islamic products, servicescape, and interpersonal communication have a positive and significant effect on customer satisfaction of BTN Syariah KCPS Ngaliyan.

Implication - This research can be used for references related to matters that affect customer satisfaction.

Originality - This study analyzes the variable attributes of Islamic products, servicescape, and interpersonal communication on customer satisfaction.
\end{abstract}

Keywords: $\quad$ Satisfaction; Islamic Product Attributes; Servicescape; Interpersonal Communication. 
Nurudin, Khoirul Anwar, Hidayaturrosyida

\section{Introduction}

Indonesia has two types of banks, namely Conventional Banks and Sharia Banks, the two types of banks are not only different in name, but also have different systems and platforms. Conventional banks are built from the economic practices of capitalism that adhere to liberalism, which is based on utility, the economic system according to this concept, said K. Bertnes, has elements such as private ownership institutions, seeking maximum profit and competing in the free market. In this system the accumulation of capital becomes the driving force and religious elements are ignored. The accumulation of capital gave birth to a group of capital owners which later developed into money and capital markets. In the money and capital markets, money is a commodity that is traded at a price represented by an interest rate.

Another case with Islamic banks, or banks that have the symbol "iB". According to (Suhirman, 2020) in Islam, all activities carried out by a Muslim must be in accordance with Islamic law, including in economic activities. In doing business in Islam, in practice always uphold the principles of justice and balance (Nurudin, 2017). This also applies to Islamic banks, which operate in accordance with sharia principles. Banks that have the word sharia are institutions that are part of the Islamic economy. Islamic banks are more focused on seeking success in the world and the hereafter. Therefore, the principles used by Islamic banks are based on the Al-Qur'an and Al-Hadith, where the bank operates by applying the principles or rules that are in the $\mathrm{Al}$ Qur'an and Hadith. The profit sharing system of the Sharia Bank itself is more transparent in that the Customer knows the profit sharing amount before the contract agreement or so-called contract in banking. Indonesia, which is dominated by the largest Muslim population, should be the largest potential customer in the Islamic financial industry, including Islamic banking (Rosyadah, Arifin, Muhtadi, \& Safik, 2020).

According to Yusuf Abdillah, et.al Indonesia is considered a newcomer who was late in starting the Islamic banking industry in 1992 (Abdillah, Rabi, \& Firli, 2020), however, Islamic banks in Indonesia have experienced an increase in 
Analysis Of The Effect Of Islamic Product ...

recent years, but it can be seen from the table above that the increase and development in the number of sharia business units that have occurred unstable, the sharia business unit must maintain or further improve these results by realizing an innovation, with the innovation for the Islamic financial industry, it will create a sense of satisfaction for customers. According to Nurudin, that Success is not the bank's ability to build loyalty. If loyalty is created, it means that the customer is satisfied (Nurudin, 2018).

Not only that, to create satisfaction, there are several ways that a company can do, especially financial institutions in order to get a sense of satisfaction in the hearts of its customers. Financial institutions need to prioritize quality, according to Murtiawati and Fataron The quality of a product can be assessed and is based on a number of criteria. different, due to differences in consumer interestand involvement (Murtiawati \& Fataron, 2019). Perceptions of quality reflect the overall feelings of consumers about a product. Products need to be innovated according to consumer needs. For Islamic banking, of course, it must prioritize products that contain sharia or Islamic elements, one of which is about product attributes. Product attributes are factors inherent in a product.

However, for banks, it is not only products that need innovation, environmental related servicescape and existing facilities and interpersonal communication between employees and customers, which may be considered simple and trivial, is also a support for improving bank performance, the higher the bank's performance, the more satisfied customers will be. with the bank's performance.

Like the statement of a customer named Surip ( 55 years old) who stated that he did not know if the products in a sharia bank were free from the element of usury, another case with the customer named Fitria (22 years), he said that the arrangement of the toilets at BTN Syariah KCPS Ngaliyan Not quite right because the position of the toilet is on the 2 nd floor where every customer who wants to go to the toilet has to pass through the desk with the employees and the location of the toilet is close to the headroom of the sub-branch, this is considered uncomfortable for him. Not only the location of the toilet, he argues that the waiting room is equipped with a television, he also deems the location 
Nurudin, Khoirul Anwar, Hidayaturrosyida

of the television inaccurate, and there is no music, so that customers who wait do not feel bored.

Intan et.al say that companies taking part in preserving the environment is a requirement for companies to operate. Meanwhile, according to Higthtower and Shariat in Kartika et al, said that the physical environment that is designed according to the wishes of employees and customers will be easier to provide satisfaction (Puspitasari, Wahyudi, Rini, \& Pangestuti, 2020). Customers will choose a company where the company provides servicescape according to what they want as well as bank employees as internal customers.

To maintain the performance of Islamic financial institutions, such things as product attributes that belong to bank products / services, dimensions of the physical environment (servicescape) inside and outside the office need to be considered and employee interpersonal communication to customers is also one of the important things to improve bank performance. sharia. If the performance of the institution can improve, it will be able to create customer satisfaction, satisfaction will make customers continue to always use the product / service and be loyal to the institution. This study aims to determine the effect of Islamic product attributes, servicescape, interpersonal communication on customer satisfaction at Bank BTN Syariah KCPS Ngaliyan.

\section{Literature Review}

\section{Islamic Product Attributes}

According to Fita thought related to production has developed since humans have needs, be it clothing, food, shelter and others (Faizah, 2019). According to Sudarno in Fita (2019), production is the process of creating a good or service that can be utilized by humans. Product attributes are parts of the product that are considered important by consumers and can be used as purchasing decisions. The relationship between product attributes and purchasing decisions because products that have unique and good attributes can influence consumer decisions in making decisions. Product attributes must also be able to attract consumers so that they can become a reference for 
Analysis Of The Effect Of Islamic Product ...

consumers in making decisions. Product attributes have a positive influence on customer satisfaction. Product attributes that can provide satisfaction to consumers can affect customer loyalty to the product. Many factors can affect consumer loyalty, one of which is product attributes and service-related attributes

Product attribute is the development of a product or service from the company so that it requires the benefits it can offer. Attributes can be company performance, reliablecompanyin service, the features of the company's products, the reputation, or the aesthetics of the company. Product attribute elements include: price, brand, packaging, labeling, warranty and complementary services.

Islamic banking is a financial institution that operates services using Islamic principles. And is a country that has the largest Muslim population in the world. Must be the biggest potential customer in the Islamic financial industry. Islamic economic and financial institutions must use a contract that is in accordance with sharia. It is necessary to implement the principles of sharia (sharia compliance) in order to increase the reputation and trust of sharia bank customers. Through joint efforts to build mutual trust.

Islamic product attributes are typical product attributes that exist in Islamic banks, in the form of product features that are in accordance with the Islamic financial system. In economic activities in Islam, there are several elements that are prohibited including, usury (addition), gharar (obscurity), gambling, things that are haram and others. So it can be interpreted that the attributes of Islamic products are components that are attached to a product that does not have elements of usury, gharar, things that are haram, gambling and others. Islamic finance requires profit sharing and other risk sharing.

\section{Servicescape}

Servicescape means the physical environment. The physical environment may include services to an interior or exterior facility. Not only that, the servicescape also includes several things including symbols, parking lots, interior and exterior design, available equipment, air temperature, and layout 
Nurudin, Khoirul Anwar, Hidayaturrosyida

plans. According to Lovelock and Wirtz (2011) in Marno and Sharul (2018) Servicescape is the style and form of the physical environment and other experimental elements found by customers where services are delivered. Servicescapes are impressions created on the senses by designing the physical environment in which services are delivered.

Servicecape is a place where services are provided or the physical environment that affects both the level of satisfaction and behavior related to purchases and provides a memorable experience to customers. Servicecape is closely related to physical style and appearance and other elements of experience encountered by customers in service delivery. Servicescape can be described with cognitive, emotional, and physiological feelings, so that some of a person's sense of taste can respond and provide information about the environment he feels.

Use of an organization's physical facilities (servicecape) refers to who performs actions within the organization's physical facilities (servicecape): customers, employees or both. Lovelock San Wirtz (2011: 284-290) states that the dimensions of the servicecape are divided into three parts, namely: 1 . Ambient conditions, 2. Spatial layout and functionality, 3. Signs, symbols and artifacts. , symbols, and artifacts). Sevicecape plays an important role in the progress of the company dealing with consumers and employees. The physical facility of the company essentially packages the services offered and communicates an external image of what is in it to the customer.

\section{Interpersonal Communication}

During the service process from the waiter to the consumer, at that time there is also a direct interaction between the employee and the consumer. Interactions that are carried out through good communication contacts will create good communication contacts with consumers and the impression that consumers get is good too. Because by forming good communication contacts can improve company performance and be able to maintain consumer loyalty, loyal consumers certainly feel satisfied in providing these services (Putri, 2016). Interpersonal communication cannot be separated from 
Analysis Of The Effect Of Islamic Product ...

communication between two or more people which is based on mutual acquaintance, respect, pleasure and comfort.

According to De Vito, in Novia defines interpersonal communication as a process of sending and receiving messages from two or more people where effects and feedback can be known immediately. In interpersonal communication, the most important thing is not the intensity in communicating but how the communication is established. According to William F. Glueek (in widjadja, 2000: 8), interpersonal communication is one of the most effective communications because it is done directly between communicators and communicants, so that it can influence one another. Interpersonal communication in general is communication between people face-to-face, each person involved in this communication influences each other's perceptions of the opponent's communication.

Interpersonal communication is composed of many interrelated processes, consisting of message production, message processing, interaction coordination and social perception. The most important thing in interpersonal communication is building relationships between people.

The effectiveness of interpersonal communication in a humanistic view has elements following: openness, empathy, supportive attitude, positive attitude and equality. Understanding the interpersonal communication process demands a symbiotic relationship between communication and relational development.

\section{Customer Satisfaction}

Satisfaction (Tjiptono et al, 2007: 197) or in English is called Satisfaction from the Latin "Satis" which means adequate and "Facio" which means doing or making. In simple terms, satisfaction can be interpreted as a way of making something adequate. Satisfaction is the response of consumers who have fulfilled their wishes.

Customer satisfaction or what is commonly referred to in banking terms, namely "customers" is a measurement or indicator that customers or service 
Nurudin, Khoirul Anwar, Hidayaturrosyida

company users are very happy with the products or services they receive. Satisfaction is a comparison between expectations and perceived experience (Lupioyadi, 2013). Customers will also feel satisfied with the service they receive if the service exceeds the service they expect. With strict screening.

Customer satisfaction is the feeling when receiving and after experiencing bank services. Satisfaction as a form of customer response to the fulfillment of their kebutuhanya. The 5 factors that determine the level of satisfaction include: product quality, service quality, emotional factors, price and cost. Satisfaction has many benefits, namely obtaining happiness, comfort, security and tranquility in the world.

There are four ways to measure the level of customer satisfaction, namely the complaint and proposal system, customer satisfaction surveys, mystery guest, and analysis of former customers. Consumers who are satisfied with products and services tend to buy back products and reuse services when the same needs reappear at a later date. Customer satisfaction is the feeling when receiving and after experiencing bank services.

\section{Methods}

Quantitative research is research that is conducted using the method of collecting data, the data is in the form of numbers, which are then processed and analyzed to produce scientific information behind the numbers. The research used by researchers uses quantitative research methods, namely by explaining the influence of Islamic product attribute variables, servicescape, and interpersonal communication (independent variables) on customer satisfaction (dependent variable) by using primary data obtained from interviews by distributing questionnaires to respondents, the respondent here means the customer of Bank BTN KCPS Ngaliyan.

Primary data (Iqbal Hasan, 2002: 82) is data whose sources are obtained directly or data collected directly in the field by researchers. This study uses primary data by distributing questionnaires to customers of Bank Tabunngan Negara (BTN) Syariah Ngaliyan Sub-Branch Office. 
Analysis Of The Effect Of Islamic Product ...

Not only that, this research also uses secondary data obtained from existing sources, for example from previous research, books, and others called secondary data (Iqbal Hasan, 2002: 58). This data is used to complement the information from the data obtained directly. Secondary data in this study were sourced from OJK publication reports, research journals and books.

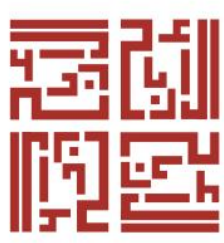

The data analysis method used in this research is descriptive analysis and data feasibility test. Descriptive analysis is a statistical method that illustrates the properties of data.

\section{Results and Discussion}

\section{F test}

The $\mathrm{F}$ test is used to find out whether the variable $\mathrm{X}$ together (simultaneously) affects variable Y. There are the results of the F test in the following table 2 .

After finding Ftable, it can be concluded that the value of Fcount is 35.085> 2.70 with a probability of $0.000<0.05$, which means that the independent variable consisting of Islamic product attributes, servicescape, and interpersonal communication together or simultaneously has a significant effect on the dependent variable, namely satisfaction customer.

Table 2. F Test Results

\begin{tabular}{lccccc}
\hline \multicolumn{5}{c}{ ANOVAa } & \\
Model & Sum of Squares & df & Mean Square & F & Sig. \\
\hline 1 Regression & 372,248 & 3 & 124,083 & 35,085 & , 000b \\
Residual & 339,512 & 96 & 3,537 & \\
$\quad$ Total & 711,760 & 99 & & \\
a. Dependent Variable: Customer Satisfaction \\
b. Predictors: (Constant), Communication, Interpersonal, Servicescape, Attributes, \\
Products, Islam
\end{tabular}


Nurudin, Khoirul Anwar, Hidayaturrosyida

Table 3. T Test Results

\begin{tabular}{|c|c|c|c|c|c|c|c|}
\hline \multirow[b]{3}{*}{ Model } & \multicolumn{5}{|c|}{ Coefficientsa } & \multirow{2}{*}{\multicolumn{2}{|c|}{ Collinearity Statistics }} \\
\hline & \multicolumn{2}{|c|}{$\begin{array}{l}\text { Unstandardized } \\
\text { Coefficients }\end{array}$} & \multicolumn{2}{|l|}{$\begin{array}{l}\text { Standardized } \\
\text { Coefficients }\end{array}$} & \multirow[b]{2}{*}{ Sig. } & & \\
\hline & B & $\begin{array}{l}\text { Std. } \\
\text { Error }\end{array}$ & Beta & t & & Tolerance & VIF \\
\hline (Constant) &,- 326 & 2,361 & &,- 138 & , 890 & & \\
\hline $\begin{array}{l}\text { Attributes. } \\
\text { Products. Islam }\end{array}$ &, 565 & , 087 &, 555 & 6,517 &, 000 &, 684 & 1,462 \\
\hline Servicescape &, 228 &, 111 &, 171 & 2,048 &, 043 &, 709 & 1,411 \\
\hline $\begin{array}{l}\text { Interpersonal } \\
\text { communication }\end{array}$ &, 191 & , 096 &, 149 & 2,002 &, 048 &, 903 & 1,108 \\
\hline
\end{tabular}

a. Dependent Variable: Customer Satisfaction

\section{T test}

The $t$ test is used to determine individually the effect of the independent variable on the dependent variable. This study uses 4 variables and 100 data, before concluding the results from the t-test table, it is necessary to look for the $\mathrm{t}$-table using the following methods: $\mathrm{df}=\mathrm{n}-\mathrm{k} ;=100-4 ;=96$. With a significant level of $0.05(5 \%)$, the T-table value obtained is 1.661 . The results of the T-table test in table 3 .

From the results of the partial test table above, it can be concluded that: 1 . Islamic product attribute variable $t$ test. Islamic product attribute variable has tcount 6,517> ttable 1,661, which means that Islamic product attribute variables have a partially significant effect on customer satisfaction; 2 . Servicescape $t$ test. The result of tcount of servicescape variable is 2.048 where the result is greater than $t$ table 1.661 , and the significance of $0.043<0.05$ means that the servicescape variable has a partially significant effect on customer satisfaction; 3 . Interpersonal communication $t$ test. The interpersonal communication variable has a value of 2.002 while the $t$ table is 1.661, then the tcount is 2.002> ttable is 1.661 and a significant level is 0.048 $<0.05$. This shows that the interpersonal communication variable has a partially significant effect on customer satisfaction. 
Analysis Of The Effect Of Islamic Product ...

\section{Conclusion}

Based on the results of data processing in a study entitled Analysis of the Effect of Islamic Product Attributes, Servicescape, and Interpersonal Communication on Customer Satisfaction at Bank BTN Syariah KCPS Ngaliyan, conclusions can be drawn as follows: 1 . Based on the research results, product attribute variables have a positive and significant effect on customer satisfaction at Bank BTN Syariah KCPS Ngaliyan, so Ho is rejected and H1 is accepted. So the first hypothesis is tested for its truth; 2 . From the research results, the servicescape variable has a positive and significant effect on customer satisfaction at Bank BTN Syariah KCPS Ngaliyan. So H0 is rejected and H2 is accepted; 3. From the results of research on interpersonal communication variables have a positive and significant effect on customer satisfaction at Bank BTN Syariah KCPS Ngaliyan, Ho is rejected and H3 is accepted.

\section{References}

Abdillah, M. Y., Rabi, M. E., \& Firli, R. N. (2020). Tawarruq Application in Islamic Banking: A Comparative Study between Malaysia and Indonesia. Al-Arbah: Journal of Islamic Finance and Banking, 2(1), 17-32. https://doi.org/http://dx.doi.org/10.21580/alarbah.v2i1.5540

Faizah, F. N. (2019). Pemikiran Muhammad Abdul Mannan Tentang Produksi. SERAMBI: Jurnal Ekonomi Manajemen Dan Bisnis Islam, 1(2), 55-68. https://doi.org/10.36407/serambi.v1i2.71

Murtiawati, M., \& Fataron, Z. A. (2019). The impact of product quality and service quality on consumer loyalty (a case study of Bandeng Rozal in Bandengan village, Kendal district, Kendal regency). Journal of Islamic Economics, 1(1), 47-118. https://doi.org/10.21580/jiemb.2019.1.1.3985

Nurudin, N. (2017). Pengaruh Sharia Marketing terhadap Loyalitas Anggota KSPPS BMT Walisongo Semarang. Muqtasid: Jurnal 
Nurudin, Khoirul Anwar, Hidayaturrosyida

Ekonomi Dan Perbankan Syariah, 8(1), 28. https://doi.org/10.18326/muqtasid.v8i1.28-41

Nurudin, N. . (2018). PENGARUH RELATIONSHIP MARKETING, CITRA PERUSAHAAN DAN KEPUASAN TERHADAP LOYALITAS NASABAH (STUDI PADA BANK RAKYAT INDONESIA SYARIAH KANTOR CABANG SEMARANG)PENGARUH RELATIONSHIP MARKETING, CITRA PERUSAHAAN DAN KEPUASAN TERHADAP LOYALITAS NASABAH (STUDI. JURNAL STIE SEMARANG, 10(1), 17-37. https://doi.org/10.33747/stiesmg.v10i1.84

Puspitasari, I., Wahyudi, S., Rini, I., \& Pangestuti, D. (2020). Investor Behavior In Green Investment Information. Journal of Islamic Finance and Banking, 2(1), 47-60. https://doi.org/10.21580/alarbah.2020.2.1.5497

Putri, N. H. (2016). PENGARUH KOMUNIKASI INTERPERSONAL DAN MUTU PELAYANAN TERHADAP KEPUASAN NASABAH. Psikoborneo: Jurnal Ilmiah Psikologi, 4(2), 198-204. Retrieved from http://ejournals.unmul.ac.id/index.php/psikoneo/article/view/4001

Rosyadah, P. C., Arifin, N. R., Muhtadi, R., \& Safik, M. (2020). Factors That Affect Savings In Islamic Banking. AL-ARBAH: Journal of Islamic Finance and Banking, 2(1), 33-46. https://doi.org/10.21580/alarbah.v2i1.5499

Suhirman. (2020). The Future Of Sharia Based Village Business Agencies Religious Response Management Of Village-Owned Enterprises In Central Lombok. AL-ARBAH: Journal of Islamic Finance and Banking, 2(1), 81-102. https://doi.org/10.21580/alarbah.v2i1.5677 